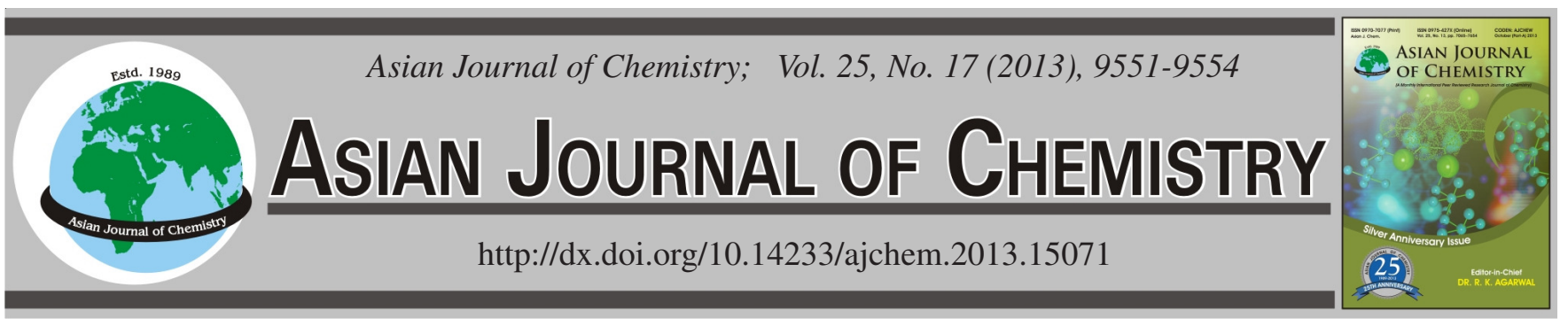

\title{
Solid-State Synthesis and Biological Property of Zinc(II) and Copper(II) Ternary Complexes of Phthalate and Imidazole
}

\author{
GuOQING ZHONG ${ }^{*}$ and YAN ZHANG
}

State Key Laboratory Cultivation Base for Nonmetal Composite and Functional Materials, Southwest University of Science and Technology, Mianyang 621010, Sichuan Province, P.R. China

*Corresponding author: Fax: +86 816 2419201; Tel: +86 816 6088252; E-mail: zgq316@163.com

\begin{abstract}
Zinc(II) and copper(II) ternary complexes of phthalate and imidazole were synthesized by room temperature solid-state reaction with $o$-phthalic acid $\left(\mathrm{H}_{2}\right.$ phth), imidazole $(\mathrm{Im})$ and zinc acetate or copper acetate as raw materials. The compositions and structures of the complexes were characterized by chemical and elemental analysis, Fourier transformed infrared spectra, X-ray powder diffraction, thermogravimetry analysis and fluorescence spectra. The results show that the compositions of the complexes are $\mathrm{Zn}(\mathrm{phth})(\mathrm{Im}) \cdot 2 \mathrm{H}_{2} \mathrm{O}$ and $\mathrm{Cu}$ (phth) $(\mathrm{Im})_{2} \cdot 2 \mathrm{H}_{2} \mathrm{O}$, respectively, the ligands are coordinated simultaneity with $\mathrm{Zn}$ (II) or $\mathrm{Cu}$ (II) via the carboxyl group of $o$-phthalic acid to form bidentate chelates and the nitrogen atom of imidazole is formed M-N bond with metal ion. Thermal decomposition processes of the complexes include dehydration, oxidation and pyrolysis of the ligands and finally as metallic oxide. Fluorescence spectra of the compound $\mathrm{Cu}($ phth $)(\mathrm{Im})_{2} \cdot 2 \mathrm{H}_{2} \mathrm{O}$ with DNA show corresponding biological activity.
\end{abstract}

Key Words: Zinc(II), Copper(II), Ternary complex, $o$-Phthalic acid, Imidazole, Room temperature solid-state synthesis, Biological activity.

\section{INTRODUCTION}

Due to the use as models for protein metal binding sites in biological systems, researchers were interested in the coordination chemistry of transition metal(II) complexes ${ }^{1}$. To devise metal-organic complexes from transition metals and organic ligands with novel architectures and design functionalities by use of the principles of crystal engineering has been challenging subjects in coordination chemistry ${ }^{2-5}$. Metal complexes of biologically important ligands are sometimes more effective than the free ligands and mixed ligands complexes play a key role in biological chemistry because the mixed chelation occurs commonly in biological fluids as millions of potential ligands are likely to compete for metal ions in vivo ${ }^{6}$. Extending the range of this work to systems involving two different organic ligands so far is less explored and it is generally not yet possible to predict either the composition or structure of the product of a reaction consisting of a metal centre and two different organic ligands ${ }^{7}$.

Transition metal complexes are commonly being used to bind and impact on specific sequences of DNA probes and for the development of highly selective diagnostic agents ${ }^{8}$. From earlier studies on the coordination behaviour of the azole ring towards some transition metal cations it follows that the complexes has been influenced not only by the ligands basicity but also by the $\pi$-donor strength of the central ions. The imidazole has currently been used as a ligand to simulate the function of the axial histidine imidazole in metalloenzymes ${ }^{9}$. Currently, phthalate, a well known and classical chelated agent in coordination chemistry, has been proved a good participator in creating metal organic frame work with mixed organic ligands. The phthalic acid has been used as a bridge in architecture of coordination polymer ${ }^{10-19}$.

Microwave heating is a promising technology whose applications have been rapidly growing due to its unique effects compared with the conventional heating, such as rapid volumetric heating, increased reaction rates and shortened reaction time, enhanced reaction selectivity and energy saving ${ }^{20}$. Room temperature solid-state reaction method is a kind of methods for the preparation of some compounds and many complexes have been synthesized by this method ${ }^{21}$. Advantages of the solid-state synthesis method are environmental friendly, much higher yield, being inexpensive, faster reaction rate and easier operating ${ }^{22}$. In this paper, we reported the results of two reactions in mixed ligands systems, successfully synthesized two ternary complexes $\mathrm{Zn}$ (phth)(Im) $\cdot 2 \mathrm{H}_{2} \mathrm{O}$ and $\mathrm{Cu}$ (phth)$(\mathrm{Im})_{2} \cdot 2 \mathrm{H}_{2} \mathrm{O}$. 


\section{EXPERIMENTAL}

Materials and physical measurements: All chemicals used in the experiments were analytical reagents as received from commercial sources with no further purification. The contents of carbon, hydrogen, nitrogen and oxygen in the products were determined by the Vario EL CUBE-Element analyzer from German Elemental Analysis System Company. Zinc and copper were measured by classical EDTA titration method and the samples were heated in the muffle furnace at $500{ }^{\circ} \mathrm{C}$ for $2 \mathrm{~h}$ and dissolved by a small quantity of diluted sulphuric acid. The X-ray powder diffraction patterns of the complexes were recorded by a D/max-YB X-ray diffractometer from Japan, $\mathrm{CuK}_{\alpha}$ radiation $(\lambda=0.154056 \mathrm{~nm})$, Ni filter, scanning rate was $8^{\circ}(2 \theta) \mathrm{min}^{-1}$ at room temperature. The infrared spectra in the region of $4000-400 \mathrm{~cm}^{-1}$ were recorded by a Nicolet 5700 Fourier transform infrared spectrometer from American using potassium bromide pellets. Thermal analyses for the complexes were performed by a TA Q500 thermal analyzer in dry nitrogen at a heating rate of $10^{\circ} \mathrm{C} \mathrm{min}^{-1}$. DNA was purchased from Jinan Wedo Industrial Co., Ltd. The fluorescence spectra were recorded on an FL-4500 spectrofluorophotometer from SHIMADZU company in Japan.

Microwave solid-state synthesis of $\mathrm{Zn}$ (phth) $\cdot 2 \mathrm{H}_{2} \mathrm{O}$ and $\mathbf{C u}$ (phth) $2 \mathbf{H}_{2} \mathrm{O}$ : To make the metal complex, $\mathrm{Zn}\left(\mathrm{CH}_{3} \mathrm{COO}\right)_{2} \cdot 2 \mathrm{H}_{2} \mathrm{O}$ or $\mathrm{Cu}\left(\mathrm{CH}_{3} \mathrm{COO}\right)_{2} \cdot 2 \mathrm{H}_{2} \mathrm{O}(0.01 \mathrm{~mol})$ and $o$-phthalic acid $\left(\mathrm{H}_{2}\right.$ phth, $\left.0.01 \mathrm{~mol}\right)$ were added to a dry agate mortar, the reaction mixture was ground with a pestle until it became homogeneous, then transferred to a crucible and placed in a laboratory microwave oven $(750 \mathrm{~W})$. In the response process there would be a lot of acidic irritant gases released, when reactants weight unchanged, stopped responding, the white powder (glaucous powder) was obtained. The resultants were washed repeatedly by distilled water and dehydrated ethanol. Last, the resultants were dried in a vacuum drying oven at $40{ }^{\circ} \mathrm{C}$ for $1 \mathrm{~d}$. The yield of the complexes was 90.6 and $95.8 \%$, for $\mathrm{Zn}$ (II) and $\mathrm{Cu}(\mathrm{II})$ complexes, respectively.

For $\mathbf{Z n}($ phth $) \cdot \mathbf{2 H}_{2} \mathbf{O}\left(\mathrm{ZnC}_{8} \mathbf{H}_{8} \mathbf{O}_{6}\right)$ : Anal. calcd. (\%): $\mathrm{Zn}$, 24.62; C, 36.19; H, 3.04; O, 36.16. Found (\%): Zn, 24.22; C, 36.08; H, 3.30; O, 36.29.

For $\mathbf{C u}($ phth $) \cdot \mathbf{2} \mathrm{H}_{2} \mathrm{O}\left(\mathrm{CuC}_{8} \mathrm{H}_{8} \mathrm{O}_{6}\right)$ : Anal. calcd. (\%): $\mathrm{Cu}$, 24.10; C, 36.44; H, 3.06; O, 36.41. Found (\%): Cu, 23.84; C, 36.18; H, 3.14; O, 36.69.

Room temperature solid-state synthesis of $\mathrm{Zn}($ phth $)(\mathrm{Im}) \cdot \mathbf{2} \mathbf{H}_{2} \mathrm{O}$ and $\mathrm{Cu}($ phth $)(\mathrm{Im})_{2} \cdot \mathbf{2 H}_{2} \mathrm{O}: 5 \mathrm{mmol}$ $\mathrm{Zn}$ (phth) $\cdot 2 \mathrm{H}_{2} \mathrm{O}$ and $5 \mathrm{mmol}$ imidazole (Im) were placed in an agate mortar and pestled continuously for four hours and then washed several times with distilled water, followed by dehydrated ethanol and dried under vacuum drying oven at $40^{\circ} \mathrm{C}$ for 1 d. $\mathrm{Cu}$ (phth) $(\mathrm{Im})_{2} \cdot 2 \mathrm{H}_{2} \mathrm{O}$ was synthesized using the same method, but the molar ratio of $\mathrm{Cu}$ (phth) $\cdot 2 \mathrm{H}_{2} \mathrm{O}$ to imidazole was 1:2. The resultants were white or light green powder and the yield was 95.7 and $94.3 \%, \mathrm{Zn}$ (II) and $\mathrm{Cu}$ (II) complexes, respectively.

For $\mathbf{Z n}($ phth $)(\mathbf{I m}) \cdot \mathbf{2} \mathbf{H}_{\mathbf{2}} \mathbf{O}\left[\mathbf{Z n C}_{\mathbf{1 1}} \mathbf{H}_{\mathbf{1 2}} \mathbf{O}_{\mathbf{6}} \mathbf{N}_{\mathbf{2}}\right]$ : Anal. calcd. (\%): Zn, 19.60; C, 39.60; H, 3.63; N, 8.40; O, 28.78. Found (\%): Zn, 19.14; C, 39.38; H, 3.42; N, 8.21; O, 28.96.

For $\mathbf{C u}($ phth $)(\mathrm{Im})_{2} \cdot \mathbf{2 H}_{2} \mathbf{O}\left[\mathrm{CuC}_{\mathbf{1 4}} \mathbf{H}_{\mathbf{1 6}} \mathbf{O}_{\mathbf{6}} \mathbf{N}_{4}\right]$ : Anal. calcd. (\%): $\mathrm{Cu}, 15.89 ; \mathrm{C}, 42.05 ; \mathrm{H}, 4.03 ; \mathrm{N}, 14.02 ; \mathrm{O}, 24.01$. Found (\%) $\mathrm{Cu}, 15.41 ; \mathrm{C}, 42.15 ; \mathrm{H}, 4.13 ; \mathrm{N}, 14.21 ; \mathrm{O}, 23.74$.

\section{RESULTS AND DISCUSSION}

X-Ray powder diffraction analysis: Fig. 1 depicted the XRD patterns of the complexes $\mathrm{Zn}$ (phth) $\cdot 2 \mathrm{H}_{2} \mathrm{O}, \mathrm{Cu}$ (phth) $\cdot 2 \mathrm{H}_{2} \mathrm{O}$, $\mathrm{Zn}$ (phth)(Im) $\cdot 2 \mathrm{H}_{2} \mathrm{O}$ and $\mathrm{Cu}($ phth $)(\mathrm{Im})_{2} \cdot 2 \mathrm{H}_{2} \mathrm{O}$. It was seen that the compound $\mathrm{Zn}$ (phth) $(\mathrm{Im}) \cdot 2 \mathrm{H}_{2} \mathrm{O}$ at $2 \theta=25.98$ and $33.62^{\circ}$ and $\mathrm{Cu}(\mathrm{phth})(\mathrm{Im})_{2} \cdot 2 \mathrm{H}_{2} \mathrm{O}$ at $2 \theta=27.98$ and $16.86^{\circ}$, respectively, produced a strong main peak and the second strong peak, while the primary and secondary strong peaks of the reactant $\mathrm{Zn}$ (phth) $\cdot 2 \mathrm{H}_{2} \mathrm{O}$ at $2 \theta=5.38$ and $10.64^{\circ}$ and $\mathrm{Cu}$ (phth) $\cdot 2 \mathrm{H}_{2} \mathrm{O}$ at $2 \theta=8.34$ and $8.26^{\circ}$ were disappeared in the complexes. The XRD patterns of the complexes had high and sharp diffractive peaks, indicating good crystals. The diffraction angle $2 \theta$, spacing and diffractive intensity of the products were different from the reactant $\mathrm{Zn}$ (phth) $\cdot 2 \mathrm{H}_{2} \mathrm{O}$ and $\mathrm{Cu}$ (phth) $\cdot 2 \mathrm{H}_{2} \mathrm{O}$, which could explain that the two products above were not simple mixing of reactants, but the formation of new compounds.

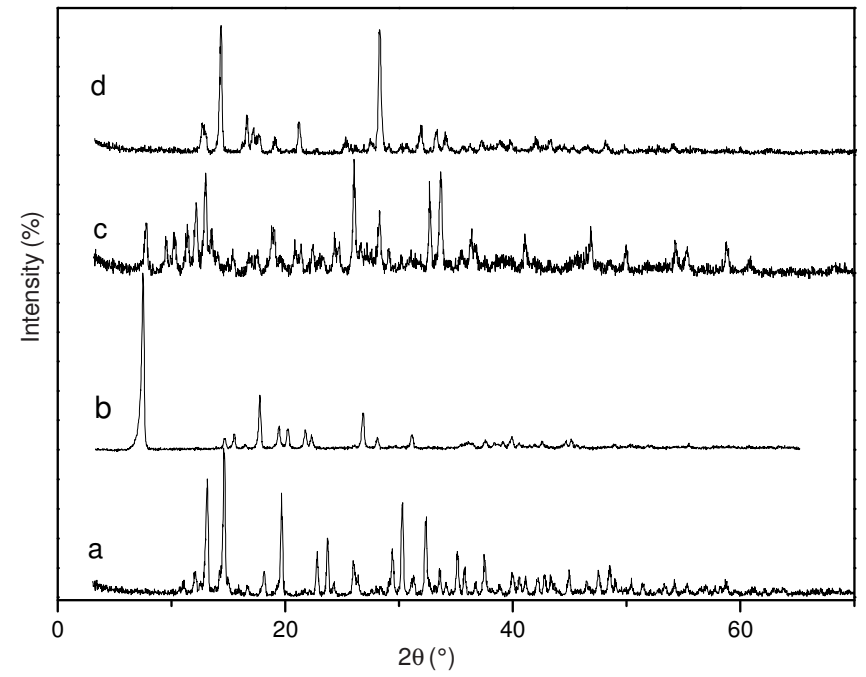

Fig. 1. XRD patterns of the complex $\mathrm{Zn}$ (phth) $2 \mathrm{H}_{2} \mathrm{O}$ (a), $\mathrm{Cu}\left(\right.$ phth) $\cdot 2 \mathrm{H}_{2} \mathrm{O}$ (b), $\mathrm{Zn}($ phth $)(\mathrm{Im}) \cdot 2 \mathrm{H}_{2} \mathrm{O}$ (c) and $\mathrm{Cu}(\mathrm{phth})(\mathrm{Im})_{2} \cdot 2 \mathrm{H}_{2} \mathrm{O}$ (d)

IR spectra: The infrared spectrums of the resultants were shown in Fig. 2. The important infrared bands of the complexes and their assignments were presented in Table-1. Generally, the absorption peaks from the stretching vibration of the $\mathrm{O}-\mathrm{H}$ bonds in the water molecule are in the range of 3550$3200 \mathrm{~cm}^{-1}$. The IR spectra of $\mathrm{Zn}(\mathrm{phth})(\mathrm{Im}) \cdot 2 \mathrm{H}_{2} \mathrm{O}$ and $\mathrm{Cu}$ (phth) $(\mathrm{Im})_{2} \cdot 2 \mathrm{H}_{2} \mathrm{O}$ showed strong absorptions at 3442 and $3426 \mathrm{~cm}^{-1}$, were due to the $v(\mathrm{O}-\mathrm{H})$ and $v(\mathrm{~N}-\mathrm{H})$ of water molecules and imidazole, which were confirmed by elemental analyses and thermoanalysis. The spectrum of the complex $\mathrm{Zn}$ (phth)(Im) $\cdot 2 \mathrm{H}_{2} \mathrm{O}$ exhibited characteristic absorption peaks at 1584 and $1384 \mathrm{~cm}^{-1}$, which were assigned to $v_{\text {as }}(\mathrm{COO})$ and $\mathrm{V}_{\mathrm{s}}(\mathrm{COO})$ stretching vibrations of the coordinated carboxyl groups $\left(\Delta v\left[v_{\text {as }}(C O O)-v_{s}(C O O)\right]=200 \mathrm{~cm}^{-1}\right)$. It indicated that the oxygen atom of the carboxyl in the complex was directly linked with the zinc ions and the presence of carboxylate groups coordinate to zinc ions in bidentate mode ${ }^{23-25}$. The complex showed characteristic frequencies of imidazole $\mathrm{C}=\mathrm{N}$ groups at $1616 \mathrm{~cm}^{-1}$. In the low-frequency region, a medium strong band at 656 and $476 \mathrm{~cm}^{-1}$ were assigned to the stretching vibration of the $\mathrm{Zn}-\mathrm{N}$ bonds and $\mathrm{Zn}-\mathrm{O}$ bonds, respectively. 


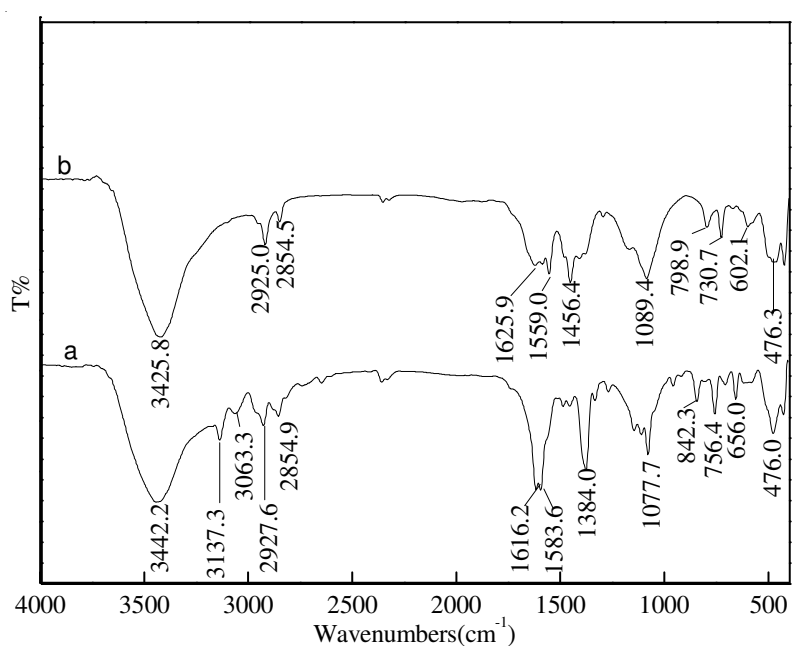

Fig. 2. FTIR spectra of $\mathrm{Zn}$ (phth)(Im) $2 \mathrm{H}_{2} \mathrm{O}$ (a) and $\mathrm{Cu}$ (phth)(Im) $)_{2} \cdot 2 \mathrm{H}_{2} \mathrm{O}$ (b)

\begin{tabular}{|c|c|c|}
\hline \multicolumn{3}{|c|}{$\begin{array}{l}\text { TABLE-1 } \\
\text { INFRARED SPECTRA DATA }\left(\mathrm{cm}^{-1}\right) \text { OF THE COMPLEXES }\end{array}$} \\
\hline Complex & $\mathrm{Zn}(\mathrm{phth})(\mathrm{Im}) \cdot 2 \mathrm{H}_{2} \mathrm{O}$ & $\mathrm{Cu}($ phth $)(\operatorname{Im})_{2} \cdot 2 \mathrm{H}_{2} \mathrm{O}$ \\
\hline$v(\mathrm{COO})$ & $1584\left(v_{\mathrm{as}}\right), 1384\left(\mathrm{v}_{\mathrm{s}}\right)$ & $1559\left(v_{\mathrm{as}}\right), 1456\left(v_{\mathrm{s}}\right)$ \\
\hline$v(\mathrm{OH})$ & 3442 & 3426 \\
\hline$v(\mathrm{Ar}-\mathrm{H})$ & $3137,3063,2928$ & 2925,2854 \\
\hline$v(C=N)$ & 1616 & 1626 \\
\hline$v(C-N)$ & $1078,842,756$ & $1089,799,731$ \\
\hline$v(\mathrm{Zn}-\mathrm{N})$ & 656 & 602 \\
\hline$v(\mathrm{Zn}-\mathrm{O})$ & 476 & 476 \\
\hline
\end{tabular}

Accordingly in the $\mathrm{Cu}(\mathrm{phth})(\mathrm{Im})_{2} \cdot 2 \mathrm{H}_{2} \mathrm{O}$, the bands at 1559 and $1456 \mathrm{~cm}^{-1}$ were correspond to the asymmetric and symmetric stretching vibration for carboxyl groups $\left(\Delta v\left[v_{\text {as }}(\mathrm{COO})\right.\right.$ $\left.\left.v_{\mathrm{s}}(\mathrm{COO})\right]=103 \mathrm{~cm}^{-1}\right)$, it indicated that the oxygen atom of the carboxyl in the compound was directly linked with the copper ions and the presence of carboxylate groups coordinate to copper ion in bidentate mode ${ }^{23-25}$. The $v(\mathrm{C}=\mathrm{N})$ band in the spectrum of the complex was shifted to $1626 \mathrm{~cm}^{-1}$, which confirmed the coordination of the imidazole nitrogen atoms and the $\mathrm{Cu}^{2+}$ ions. A medium strong band at 602 and $476 \mathrm{~cm}^{-1}$ were assigned to the stretching vibration of the $\mathrm{Cu}-\mathrm{N}$ bonds and $\mathrm{Cu}-\mathrm{O}$ bonds, respectively.

Thermal decomposition process: The thermal decomposition process of complexes is helpful to the understanding of the coordination structure of the complexes ${ }^{26}$. The TGDTG curves of the complexes were obtained at a heating rate of $10{ }^{\circ} \mathrm{C} \min ^{-1}$, which were shown in Figs. 3 and 4 . The thermal stability of the complexes $\mathrm{Zn}(\mathrm{phth})(\mathrm{Im}) \cdot 2 \mathrm{H}_{2} \mathrm{O}$ and $\mathrm{Cu}$ (phth) $(\mathrm{Im})_{2} \cdot 2 \mathrm{H}_{2} \mathrm{O}$ were examined representatively by thermaogravemetric analysis in nitrogen atmosphere from $40-600{ }^{\circ} \mathrm{C}$. In the thermaogravemetric curve of the complex $\mathrm{Zn}$ (phth)(Im) $2 \mathrm{H}_{2} \mathrm{O}$, it displayed three main steps of weight losses (Fig. 3). The weight loss from $270.43-350.53{ }^{\circ} \mathrm{C}$ was observed ca. $31.65 \%$ (calculated $31.21 \%$ ), corresponding to the release of all the lattice water molecules and imidazole. Upon further heating, the complex $\mathrm{Zn}(\mathrm{phth})(\mathrm{Im}) \cdot 2 \mathrm{H}_{2} \mathrm{O}$ decomposed slowly until $c a .600{ }^{\circ} \mathrm{C}$, among which the ligands were partially burnt, only inorganic compound $\mathrm{ZnO}$ was obtained and its weight content was $24.93 \%$ (calculated $24.39 \%$ ). These results further ascertained the sample was composed of $\mathrm{Zn}$ (phth)(Im) $2 \mathrm{H}_{2} \mathrm{O}$. In Fig. 4, the first weight loss of $9.06 \%$

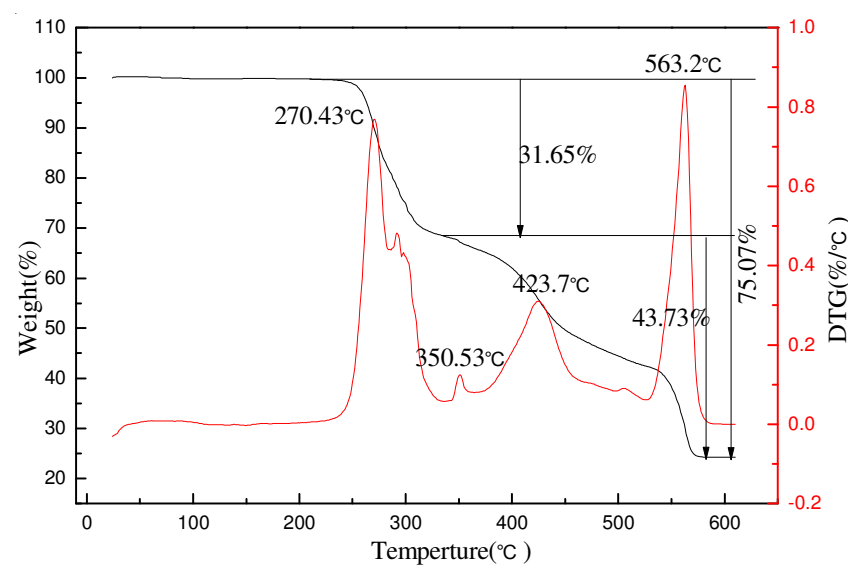

Fig. 3. TG-DTG curves of $\mathrm{Zn}(\mathrm{phth})(\mathrm{Im}) \cdot 2 \mathrm{H}_{2} \mathrm{O}$

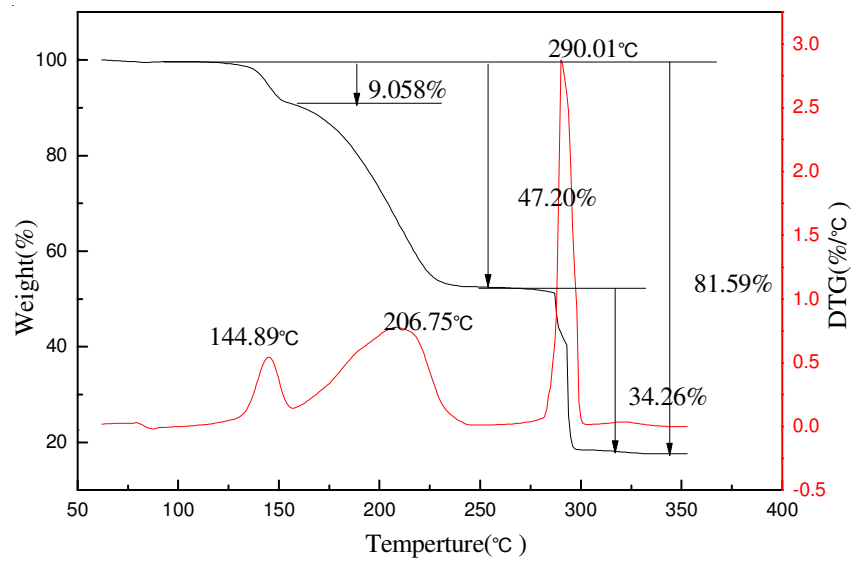

Fig. 4. TG-DTG curves of $\mathrm{Cu}($ phth $)(\mathrm{Im})_{2} \cdot 2 \mathrm{H}_{2} \mathrm{O}$

for the complex $\mathrm{Cu}(\mathrm{phth})(\mathrm{Im})_{2} \cdot 2 \mathrm{H}_{2} \mathrm{O}$ occurred in the temperature range of $118-144.89^{\circ} \mathrm{C}$, which corresponded to the loss of two water molecules per formula (calculated $9.01 \%$ ). On further heating, in the $\mathrm{Cu}$ (phth) $(\mathrm{Im})_{2} \cdot 2 \mathrm{H}_{2} \mathrm{O}$ the weight loss of $81.59 \%$ occurred between 118 and $290^{\circ} \mathrm{C}$, which agreed with calculated values of $80.11 \%$ for the release of the water molecules, $o$-phthalic acid and imidazol ligands, to give the expected metallic oxide. These results further ascertained the sample was composed of $\mathrm{Cu}(\mathrm{phth})(\mathrm{Im})_{2} \cdot 2 \mathrm{H}_{2} \mathrm{O}$. Because of the high temperature lost water, the water molecules of the complexes could be coordinated.

Absorption fluorescence spectra: At room temperature, excitation wavelength was $441 \mathrm{~nm}$, scan range 480-560 nm, both excitation slit and emission slit $10.00 \mathrm{~nm}$. The absorption fluorescence spectra titrated with complexes were conducted, which dissolved in aqueous solution putting $3.00 \mathrm{~mL}$ the complex solution in $1.00 \mathrm{~cm}$ comparison dish and by adding of DNA solution $(10 \mu \mathrm{L}$ each time. The voluminal effect was so small that could be ignored.). Fixed the concentration of the complex $\mathrm{Cu}($ phth $)(\mathrm{Im})_{2} \cdot 2 \mathrm{H}_{2} \mathrm{O}$, gradually changing the concentration of DNA, scanned the fluorescence of system (Fig. 5). The results showed that the concentration of DNA was increased, the fluorescence intensity of the complex $\mathrm{Cu}$ (phth)(Im) $)_{2} \cdot 2 \mathrm{H}_{2} \mathrm{O}$ gradually increased. The experimental results indicated that there was an interaction between the complex $\mathrm{Cu}(\mathrm{phth})(\mathrm{Im})_{2} \cdot 2 \mathrm{H}_{2} \mathrm{O}$ and $\mathrm{DNA}^{27}$ and the complex showed corresponding biological activity. 


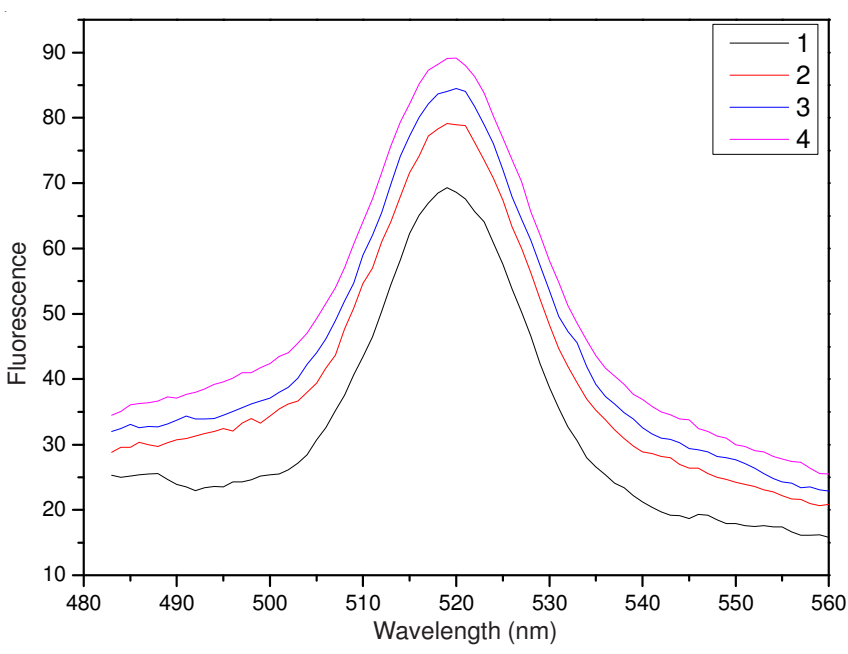

Fig. 5. Fluorescence spectra of $\mathrm{Cu}(\mathrm{phth})(\mathrm{Im})_{2} \cdot 2 \mathrm{H}_{2} \mathrm{O}$-DNA (The fluorescence spectra of $\mathrm{Cu}(\mathrm{phth})(\mathrm{Im})_{2} \cdot 2 \mathrm{H}_{2} \mathrm{O}$ in different concentrations of DNA. $\mathrm{c}(\mathrm{DNA})=2.00 \times 10^{-5} \mathrm{~mol} \mathrm{~L}^{-1}(10 \mu \mathrm{L}$ per scan $\left.), \mathrm{c}\left[\mathrm{Cu}(\mathrm{phth})(\mathrm{Im})_{2} \cdot 2 \mathrm{H}_{2} \mathrm{O}\right]=2.00 \times 10^{-4} \mathrm{~mol} \mathrm{~L}^{-1}\right)$

\section{Conclusion}

$\mathrm{Zn}$ (II) and $\mathrm{Cu}(\mathrm{II})$ coordination compounds with $o$ phthalic acid and imidzole ligands, with the composition $\mathrm{Zn}$ (phth) $(\mathrm{Im}) \cdot 2 \mathrm{H}_{2} \mathrm{O}$ and $\mathrm{Cu}($ phth $)(\operatorname{Im})_{2} \cdot 2 \mathrm{H}_{2} \mathrm{O}$, were synthesized by room temperature solid-state reaction. The structure and properties of the ternary complexes were investigated. The results of IR spectra showed that the oxygen atom of the carboxyl in the complexes was directly linked with the metal ions and the presence of carboxylate groups was coordinated to metal ions in bidentate mode. Thermal decomposition processes of the complexes included dehydration, oxidation and pyrolysis of the ligands and finally as metallic oxide. The result of the absorption fluorescence spectra indicated that there was an interaction between $\mathrm{Cu}(\mathrm{phth})(\mathrm{Im})_{2} \cdot 2 \mathrm{H}_{2} \mathrm{O}$ and DNA, which showed corresponding biological activity.

\section{ACKNOWLEDGEMENTS}

This work is supported by Scientific Research Funds of Sichuan Provincial Education Department in China (10ZA016). The authors are very grateful to State Key Laboratory Cultivation Base for Nonmetal Composite and Functional Materials, Engineering Research Center of Biomass Materials of Education Ministry and Analysis Test Center of Southwest University of Science and Technology for the testing of elemental analyses, XRD, IR spectra and TG-DTG.

\section{REFERENCES}

1. C.H. Ye, H.L. Sun, X.Y. Wang, R.L. Huang, J.R. Li and S. Gao, J. Chem. Crystallogr., 35, 381 (2005).

2. Y.S. Song, B. Yan and Z.X. Chen, Appl. Organomet. Chem., 20, 44 (2006).

3. P. Kapoor, A. Pathak, R. Kapoor and P. Venugopalan, Inorg. Chem., 23, 6153 (2002).

4. J.Y. Lu, K.A. Runnels and C. Norman, Inorg. Chem., 40, 4516 (2001).

5. Z.F. Chen, R.G. Xiong, B.F. Abrahams, X.Z. You and C.M. Che, J. Chem. Soc., Dalton Trans., 2453 (2001).

6. H.A. Ewais, Trans. Met. Chem., 34, 539 (2009).

7. P. Lightfoot and A. Snedden, J. Chem. Soc., Dalton Trans., 3549 (1999).

8. H.L. Wu, J.K. Yuan, Y. Bai, F. Jia, B. Liu, F. Kou and J. Kong, Transition Met. Chem., 36, 819 (2011).

9. R. Li, J.L. Tian, H. Liu, S.P. Yan, S.W. Guo and J.Y. Zhang, Transition Met. Chem., 36, 811 (2011).

10. L. Tian, L. Chen and X. Zhang, J. Chem. Crystallogr., 40, 664 (2010).

11. X.L. Wang, Q. Chao, E.B. Wang and L. Xu, J. Mol. Struct., 737, 49 (2005).

12. C.B. Ma, C.N. Chen, Q.L. Liu, D.Z. Liao, L.C. Li and L.C. Sun, New J. Chem., 27, 890 (2003).

13. S.H. Dalt, M.R.J. Elsegood and S. Kainth, Acta Crystallogr. C, 59, m505 (2003).

14. S.G. Baca, I.G. Filippova, O.A. Gherco, M. Gdaniec, Y.A. Simonov, N.V. Gerbeleu, P. Franz, R. Basler and S. Decurtins, Inorg. Chim. Acta, 357, 3419 (2004).

15. R.H. Gao, Asian J. Chem., 24, 2823 (2012).

16. H.L. Zhu, J.L. Lin, W. Xu, J. Zhang and Y.Q. Zheng, J. Coord. Chem., 64, 2088 (2011).

17. S.W. Jin and D.Q. Wang, J. Coord. Chem., 64, 1940 (2011).

18. L. Tian, L.C. Yu, L. Chen and W.Q. Xia, J. Coord. Chem., 60, 1847 (2007).

19. W. Wu and J.M. Xie, J. Coord. Chem., 61, 2288 (2008).

20. G.Q. Zhong and R.Q. Zeng, Chin. J. Inorg. Chem., 18, 849 (2002).

21. P.G. Avaji, S.A. Patil and P.S. Badami, Transition Met. Chem., 33, 275 (2008).

22. M. Méret and S. Bienz, Eur. J. Org. Chem., 33, 5518 (2008).

23. G.B. Deacon and R.J. Philips, Coord. Chem. Rev., 33, 227 (1980).

24. K. Nakamoto, Infrared and Raman Spectra of Inorganic and Coordination Compounds, New York: Wiley \& Sons (1986).

25. B. Xu and B. Yan, Spectrosc. Lett., 39, 237 (2006).

26. G.Q. Zhong, J. Shen, Q.Y. Jiang, Y.Q. Jia, M.J. Chen and Z.P. Zhang, J. Therm. Anal. Calorim., 92, 607 (2008).

27. H.Z. Pan, X.M. Wang, H.B. Li, Q. Yang and L.S. Ding, J. Coord. Chem., 63, 4347 (2010). 